\title{
First Record of Pediobius pyrgo (Walker) (Hymenoptera: Eulophidae) in South America and its Emergence from Egg Sacs of Latrodectus geometricus C. L. Koch (Araneae: Theridiidae)
}

\author{
Karine Schoeninger ${ }^{\circledR}$, Diego Galvão de Pádua ${ }^{1}$, Lidianne Salvatierra ${ }^{2}$, Marcio Luiz de Oliveira1
}

1. Instituto Nacional de Pesquisas da Amazônia, e-mail: karine.schoeninger@gmail.com (Autor para correspondência ${ }^{\bowtie}$ ), paduadg@gmail.com, marciooliveirainpa@gmail.com. 2. The George Washington University, e-mail: $\underline{\text { lidiannetrigueiro@gmail.com. }}$

\section{EntomoBrasilis 8 (1): 79-81 (2015)}

Abstract. We record the first occurrence of Pediobius pyrgo (Walker) (Hymenoptera: Eulophidae) for South America. This is also the first report of P. pyrgo emerging from egg sacs of Latrodectus geometricus C. L. Koch (Araneae: Theridiidae).

Keywords: Brazil; Chalcidoidea; Parasitism; Spider; Wasps.

\section{Primeiro Registro de Pediobius pyrgo (Walker) (Hymenoptera: Eulophidae) na América do Sul e sua Emergência em Sacos de Ovos de Latrodectus geometricus C. L. Koch (Araneae: Theridiidae)}

Resumo. Registramos pela primeira vez a ocorrência de Pediobius pyrgo (Walker) (Hymenoptera: Eulophidae) para a América do Sul. Este também é o primeiro relato de P. pyrgo emergindo de sacos de ovos de Latrodectus geometricus C. L. Koch (Araneae: Theridiidae).

Palavras-Chave: Aranha; Brasil; Chalcidoidea; Parasitismo; Vespas.

T[ The genus Pediobius is composed by small wasps (0.8 $1.6 \mathrm{~mm}$ ), caracterized by having propodeum medially with 2 subparallel carinae diverging posteriorly and with distinct plicae; frontofacial sutures distinct, petiole in most species with ventrally pointed extension (YEFREMOVA et al. 2008; HANSSON 2013). It is a large genus of Eulophidae with 217 known species worldwide, of which 28 occur in the Neotropics (Hansson 2009; Noyes 2014). The specie Pediobius pyrgo (Walker) occurs in Europe, Japan, Korea, USA and Honduras, for the latter there are reports that five females were created from eggs sacs of Theridiidae (Araneae) (unknown specie) (Hansson 2009). From Brazil, only Pediobius furvus (Gahan) is reported (Hansson 2009, 2013).

Species of Pediobius (Eulophidae) can act as parasitoids on eggs, larvae or pupae, or as hyperparasitoids on a wide range of insects as well as egg sacs of cobweb spiders (Theridiidae) (KERRICH 1973; BoučEK 1988; HANSSON 2009, 2013).

Latrodectus is a cosmopolitan spidergenus (Araneae:Theridiidae) commonly known as widow spiders and most species can be easily recognized by the presence of red abdominal marks and by the egg sac, which has a war-mace aspect (ABALOS 1962). Several Hymenoptera have been reported as parasitoids of egg sacs of Latrodectus (Table 1) (Dozier 1931; Pierce 1939; Fullaway 1953; BOUCEK 1988; BRAMBILA \& Evans 2001; SchwarZ 2002).

Only record of Pediobius brachycerus (Thomson) as endoparasitoid of egg sacs of Latrodectus tredecimguttatus (Rossi) is known (YeFremova et al. 2010). There were no records of Pediobius as endoparasitoids of egg sacs of Latrodectus geometricus C. L. Koch. Here we report the first record of $P$. pyrgo from South America; it is also the first record of $P$. pyrgo emerging from egg sacs of L. geometricus.
One live adult female of L. geometricus (Figure 6) with two egg sacs collected in a garden area of Manaus (Amazonas, Brazil $3^{\circ} 7{ }^{\prime} 56^{\prime \prime} \mathrm{S} 59^{\circ} 58^{\prime} 24^{\prime \prime} \mathrm{W}$ ) was put in glass vial and delivered to the Laboratory of Hymenoptera at INPA. Based on observation that one egg sac had external morphological abnormalities both egg sacs were isolated. After three days small wasps started to emerge from the egg sacs, and were identified as P. pyrgo (Figures 1-5), based on the key by Schauff et al. (1997), and HANsson (2013), and afterwards confirmed by Dr. Christer Hansson (Zoological Museum, Lund University, Sweden). The images were made using a Leica (M165C) stereomicroscope with a DFC420 digital camera. Stacks of images was combined using the program Leica Application Suite v3.4.1 (Version 2009). Vouchers of host spiders, egg sacs and parasitoids were deposited at the INPA collection under the number 8799 .

In order to collect more specimens to examine the host-parasite interaction between Pediobius and Latrodectus, a visit to the same garden where the egg sacs were first collected was conducted. As result we collected three females and two males of L. geometricus and five egg sacs which were kept individually isolated in glass vials until spiderlings or parasitoids emerged. After eight days, 31 specimens of $P$. pyrgo emerged from only two egg sacs (9 and 22 parasites in each egg sac, respectively) (Figure 7). After the emergence of the parasitoids, all egg sacs of L. geometricus were examined for the presence of other parasitoids, but none was found, indicating that $P$. pyrgo is a primary parasitoid of $L$. geometricus.

Funding Agencies: CAPES (Coordenação de Aperfeiçoamento de Pessoal de Nível Superior) and Conselho Nacional de Desenvolvimento Científico e Tecnológico - CNPq through the Ciência sem Fronteiras program. 
Table 1. Species of Hymenoptera parasitoids of Latrodectus egg sacs.

\begin{tabular}{|c|c|c|c|c|}
\hline Family & Species & Host & Local and period of research & Reference \\
\hline \multicolumn{5}{|l|}{ Eurytomidae } \\
\hline & Eurytoma latrodecti Fullaway & Latrodectus geometricus (Koch) & & FULLAWAY 1953 \\
\hline & & Latrodectus hasselti Thorell & - & BOUCEK 1988 \\
\hline & & Latrodectus mactans (Fabricius) & - & BOUCEK 1988 \\
\hline \multicolumn{5}{|l|}{ Eulophidae } \\
\hline & Pediobius brachycerus (Thomson) & Latrodectus tredecimguttatus (Rossi) & Turkey/2006-2008 & YeFremova et al. 2010 \\
\hline \multicolumn{5}{|c|}{ Ichneumonidae } \\
\hline & Gelis latrodectiphagus (Hesse) & Latrodectus indistinctus (Cambridge) & - & Yu et al. 2012 \\
\hline & Gelis karakurti Rossikov & L. mactans & - & Yu et al. 2012 \\
\hline & Gelis marikovskii Kuzin & L. mactans & - & Yu et al. 2012 \\
\hline & Gelis scvarskii (Rossikov) & L. mactans & - & Yu et al. 2012 \\
\hline & Thaumatogelis neesii Förster & L. mactans & - & Yu et al. 2012 \\
\hline & Tromatobia ornata (Gravenhorst) & L. mactans & - & Yu et al. 2012 \\
\hline & Tromatobia ovivora (Boheman) & L. mactans & - & Yu et al. 2012 \\
\hline \multicolumn{5}{|c|}{ Platygastridae } \\
\hline & Baeus latrodecti Dozier & L. mactans & Haiti/ October 1930 & DOZIER 1931 \\
\hline & Baeus californicus Pierce & L. geometricus & Los Angeles/ August 1938 & PIERCE 1939 \\
\hline & & L. mactans & Los Angeles/ August 1938 & Pierce 1939 \\
\hline
\end{tabular}

- There are no information about the place and period of research, only reports of the parasitoids area cited.
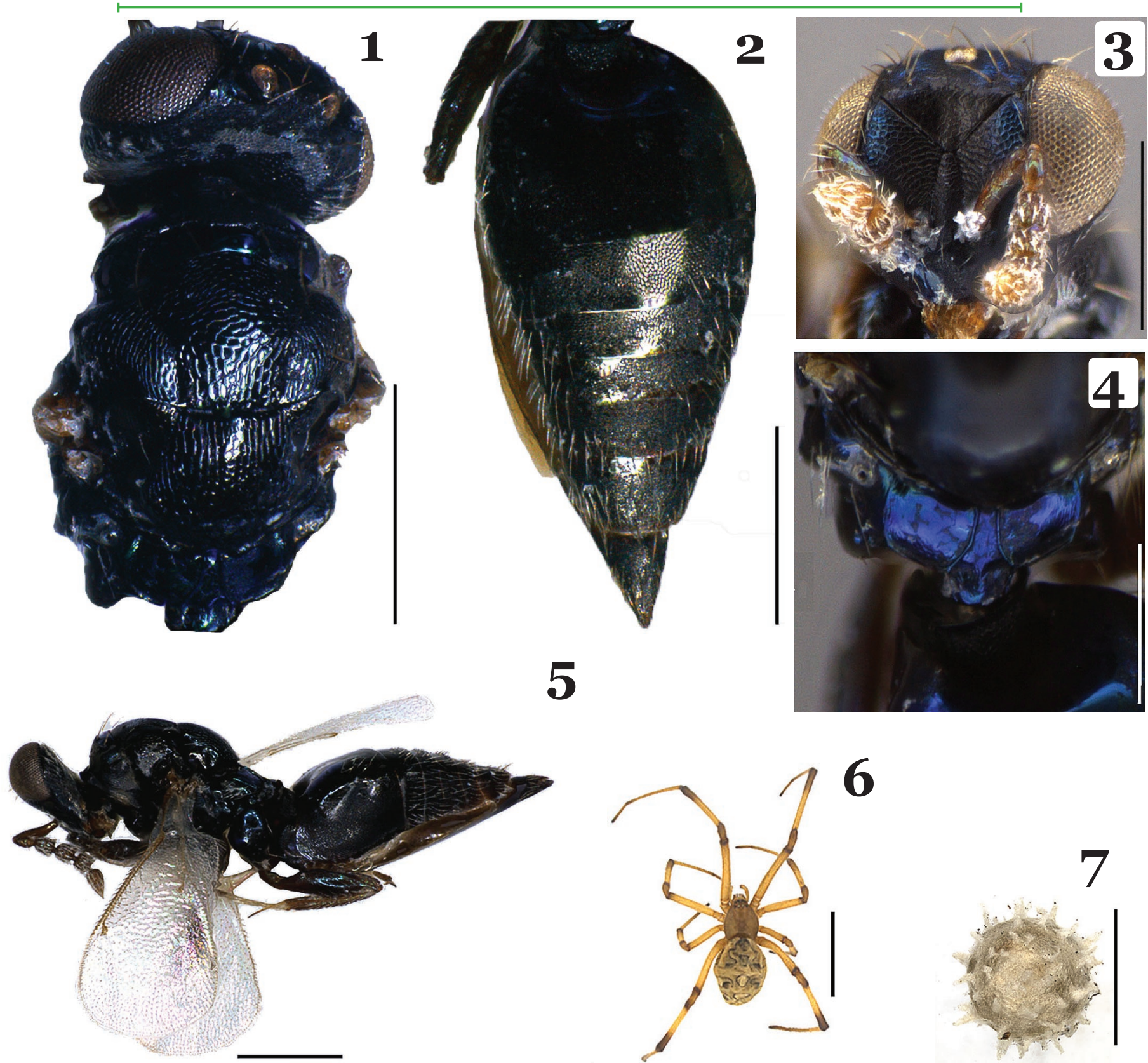

Figures 1-7. Pediobius pyrgo, female: 1. Head and mesosoma, dorsal view (scale bar $=200 \mu \mathrm{m}) ; 2$. Gaster, dorsal view $(\mathrm{scale}$ bar $=200 \mu \mathrm{m}) ; 3 . \mathrm{Head}$, frontal view (scale bar $=200 \mu \mathrm{m}) ; 4$. Propodeum, dorsal view (scale bar $=100 \mu \mathrm{m}) ; 5$. Habitus, lateral view $(\mathrm{scale}$ bar $=100 \mu \mathrm{m}) ; 6$. Latrodectus geometricus, dorsal view (scale bar $=5 \mathrm{~mm}$ ); 7. P. pyrgo, after hatch, on an egg sac (scale bar $=5 \mathrm{~mm}$ ). 
So far there is no information regarding the introduction of $P$. pyrgo in South America. However, we believe that this species occurs naturally in Brazil, since their hosts are also present. The observation of the emergence of $P$. pyrgo from the egg sacs of L. geometricus is relevant since contributes with information on the host-parasite biology.

\section{ACKNOWLEDGEMENTS}

Dr. Christer Hansson (Zoological Museum, Lund University, Sweden) kindly assisted with the identification of the species. CAPES (Coordenação de Aperfeiçoamento de Pessoal de Nível Superior) for the scholarship to KS and DGP. Conselho Nacional de Desenvolvimento Científico e Tecnológico - $\mathrm{CNPq}$ through the Ciência sem Fronteiras program - CSF (grant CSF\# 200494/2013-9 to LS). CAPES Pro-Equipamentos, Dra. Neusa Hamada/CNPq for providing photographic equipment.

\section{REFERENCES}

Abalos, J.W., 1962. The egg-sac in the identification of species of Latrodectus (Black - Widow Spiders). Psyche, 69: 268-270.

Boucek, Z., 1988. Australasian Chalcidoidea (Hymenoptera): A Biosystematic Revision of Genera of Fourteen Families, with a Reclassification of species. CAB International, Wallingford, Oxon, U.K., Cambrian News Ltd., Aberystwyth, Wales, 108 p.

Brambila, J. \& G.A. Evans, 2001. Hymenopteran parasitoids associated with spiders in Florida. Insecta Mundi, 15: 1-18.

Dozier, H.L., 1931. A new scelionid egg parasite of the black widow spider. Proceedings of the Entomological Society of Washington, 33: 27-28.

Fullaway, D.T., 1953. Three new species of Eurytoma (Hymenoptera: Eurytomidae). Proceedings of the Hawaiian Entomological Society, 15: 33-36.

Hansson, C., 2009. Catalogue of the Eulophidae in the Neotropical region. Available in: <http://www.neotropicaleulophidae.
com/pdfs/Catalogue.pdf> [Accessed: 09.18. 2013].

Hansson, C., 2013. Neotropical Eulophidae. Available from: Available in: <http://www.neotropicaleulophidae.com> [Accessed: 09.04.2013].

Kerrich, G.J., 1973. A revision of tropical and subtropical species of the Eulophid genus Pediobius Walker (Hymenoptera: Chalcidoidea). Bulletin of the British Museum (Natural History), 29: 115-199.

Noyes, J.S., 2014. Universal Chalcidoidea Database. World Wide electronic publication. Available in: <http://www.nhm. ac.uk/chalcidoids >. [Accessed: 01.07.2015].

Pierce, W.D., 1939. The black widow spider and its parasites. Bulletin of the Southern California Academy of Sciences, 37: 101-104.

Schauff, M.E., J. LaSalle \& L.D. Coote, 1997. Eulophidae, p. 327-429. In: Gibson, G.A.P., J.T. Huber \& J.B. Woolley (Eds.). Annotated keys to the genera of Neartic Chalcidoidea (Hymenoptera). NRC Research Press, Ottawa, 794 p.

Schwarz, M., 2002. Revision der westpaläarktischen Arten der Gattungen Gelis Thunberg mit apteren Weibchen und Thaumatogelis Schwarz (Hymenoptera, Ichneumonidae). Teil 3. Linzer Biologische Beiträge, 34: 1293-1392.

Yefremova, Z., 2008. Order Hymenoptera, Family Eulophidae. Arthropod Fauna of the UAE, 1: 345-360.

Yefremova, Z., H.S. Civelek, P.S. Boyadzhiev, O. Dursun \& A. Eskin, 2010. Türkiye Entomoloji Dergisi, 34: 447-463.

Yu, D.S., C. van Achterberg, \& K. Horstmann, 2012. World Ichneumonoidea 2011: Taxonomy, Biology, Morphology and Distribution. Taxapad 2012, Vancouver, Available in: <http://www.taxapad.com >. [Accessed: 01.07.2015].

\section{Received in: 09/03/2014}

Accepted in: 01/20/2015

$* * * * * * * * *$

\section{Suggested citation:}

Schoeninger, K., D.G. Pádua, L. Salvatierra \& M.L. Oliveira, 2015. First Record of Pediobius pyrgo (Walker) (Hymenoptera: Eulophidae) in South America and its Emergence from Egg Sacs of Latrodectus geometricus C. L. Koch (Araneae: Theridiidae). EntomoBrasilis, 8 (1): 79-81. Available in: $\underline{\text { doi:10.12741/ebrasilis.v8i1.470 }}$
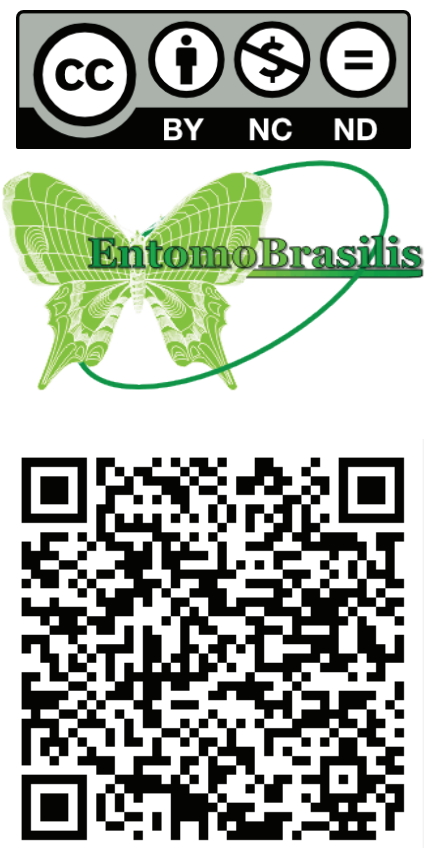